\title{
THE ECONOMIC IMPACTS OF DROUGHTS: A FRAMEWORK FOR ANALYSIS
}

Jaume Freire-González ${ }^{1}$

Christopher Decker ${ }^{2}$

Jim W. Hall ${ }^{1}$

1 Environmental Change Institute, University of Oxford, Oxford University Centre for the Environment, South Parks Road, Oxford, OX1 3QY UK.

${ }^{2}$ Centre for Socio-Legal Studies, University of Oxford, Manor Road Building, Oxford OX1 3UQ.

\begin{abstract}
Droughts are a specific type of natural hazard. Economic assessments of drought impacts require a framework capable of accounting for its unique and particular characteristics. Traditional conceptual frameworks used to assess the impacts of natural hazards do not adequately capture all of the factors that contribute to the economic impacts of droughts, such as: the importance of the level, and composition, of hydraulic capital; the dispersion of economic impacts across different economic activities and agents; the temporality of drought events; and the critical importance of policy-making in shaping the short and long-term economic impacts of droughts. Nor do traditional frameworks take account of the complex interaction between factors within the domain of decision-making and underlying climate conditions. We propose a new conceptual framework based around two sources of economic impact: 'green water' and 'blue water', and argue that because each source of drought impacts the economy in different ways, they must be differentiated in any assessment of economic impact.
\end{abstract}

\section{Keywords}

Drought; economic impacts; policy; hydraulic capital; water economics. 


\section{INTRODUCTION}

In economic terms drought is a special type of natural hazard. Droughts display specific spatial and temporal characteristics, and are heavily impacted by policy choices over the short and long term. The unique and particular characteristics of droughts means that the standard analytical frameworks used to estimate the economic impacts of other types of natural hazards -such as floods, earthquakes and hurricanes-are not automatically fit for purpose when applied to droughts.

Many regions of the world are currently experiencing some of the worst drought conditions for a number of generations. In 2014, Brazil experienced its worst drought in 80 years, while California has recently endured its worst drought for over a century. Over the past decade, prolonged and severe droughts have also been experienced in Africa, Southern Europe and Australasia. Projections suggest that droughts will be more frequent and severe in many parts of the world as a result of population growth, rising incomes and changes in climatic conditions (IPCC, 2014). In responding to drought policy-makers, regulators, water companies and other stakeholders need a deeper understanding of the trade-offs involved with different management options, having regard to costs and the potential impacts on economic systems. This, in turn, increases the importance of developing an appropriate framework for understanding the impacts of drought and the costs associated with different policy measures. By highlighting the trade-offs and choices involved the framework described in this paper is intended to assist policy-makers, regulators, water companies, water users and other stakeholders in managing and responding to drought over the short and long-term.

Traditional methodologies for measuring the (macroeconomic) impacts of drought assess the economic effects of droughts across a range of different regions from an empirical perspective (surveys of studies can be found at Ding et al., 2010, Logar and van den Bergh, 2013 and in Meyer et 
al., 2013). An important focus of most of this work has been on assessing the impact of drought on agriculture activities (e.g. Islam, 2003; Horridge et al., 2005; Wittwer and Griffith, 2010; Osman et al., 2014; Howitt et al., 2014). While this focus is appropriate for highly agricultural economic regions, it is of less relevance when assessing the potential impact of drought in economic regions that are less reliant on agriculture or which have a more complex and diversified industrial structure. In these settings, there is a need for a more general analytical framework that can assess impacts for all economic sectors and activities. This research sets out such a general conceptual framework for assessing the economic impacts of droughts, emphasising how policy decisions, responses and planning interact. An important element of the framework is that it recognises that drought is a complex phenomenon with several and wide economic implications.

We have organised our description of the framework into 7 sections. Section 2 describes the standard empirical approaches to assess the costs or impacts of natural hazards. It also provides an overview of selected empirical studies on the costs of droughts. Section 3 identifies some of the distinguishing features and characteristics of droughts from an economic perspective. Section 4 describes the two main sources of economic cost or impact of droughts and how they impact on economies. Section 5 analyses the role of hydraulic capital on the economics of droughts. Section 6 focuses on how shortterm drought or water management policies can affect the economic impacts, while section 7 sets out our main conclusions.

\section{CHARACTERIZATION OF ECONOMICS OF DROUGHTS}

This section characterizes the main aspects to consider in drought economics focusing on costs, impacts and empirical evidence. It highlights the complexity of drought and discusses how droughts differ from other natural hazards in economic terms. 


\subsection{Cost categories used to assess natural hazards}

The main cost categories used to assess and estimate the impact of different shocks associated with natural hazards include (Smith and Ward, 1998; Penning-Rowsell et al., 2003; Meyer et al., 2013):

- Direct costs: including damages to assets such as buildings, contents and infrastructure; production interruption because of destroyed machinery; shortages of productive inputs or reduction of labour or its productivity.

- Indirect costs and associated economy wide impacts: indirect costs are induced production losses of suppliers and customers of economic agents directly affected by a hazard (Przyluski and Hallegatte, 2011).

- Intangible costs: damages to goods and services which are not measurable (or at least not easily measurable) in monetary terms because they are not traded on a market. Damages to environmental goods or services, physical and mental health, pollution, environmental loads and other externalities are included within this category.

- Risk mitigation costs: these can be directly incurred costs (such as those involved in the setup of infrastructure and operation and maintenance costs) and indirect costs which are induced costs in other sectors.

The estimation of intangible costs can often be complicated by the fact that it involves the monetization of non-market goods and services, as well a need to make a decision on discount rates (Padilla, 2002). Similarly, the estimation of risk mitigation costs is often controversial because the estimation of such costs can require the development of an appropriate counterfactual. That is, the risk mitigation cost need to be assessed having regard to the expected probability of an event of a particular magnitude, length and frequency being incurred, and then compared to the potential costs associated with taking preventative measures to avoid such an event arising in the first instance. 
Beyond these cost categories, the redistribution effects of natural hazards also need to be considered if a complete assessment of the economic impacts of natural hazards is to be undertaken.

\subsection{Costs of droughts}

Droughts imply several types of economic impact and associated cost. Fig. 1 shows the different pathways to economic impacts of a drought. The pathways are interrelated given that economies are complex systems with all sorts of feedback effects.

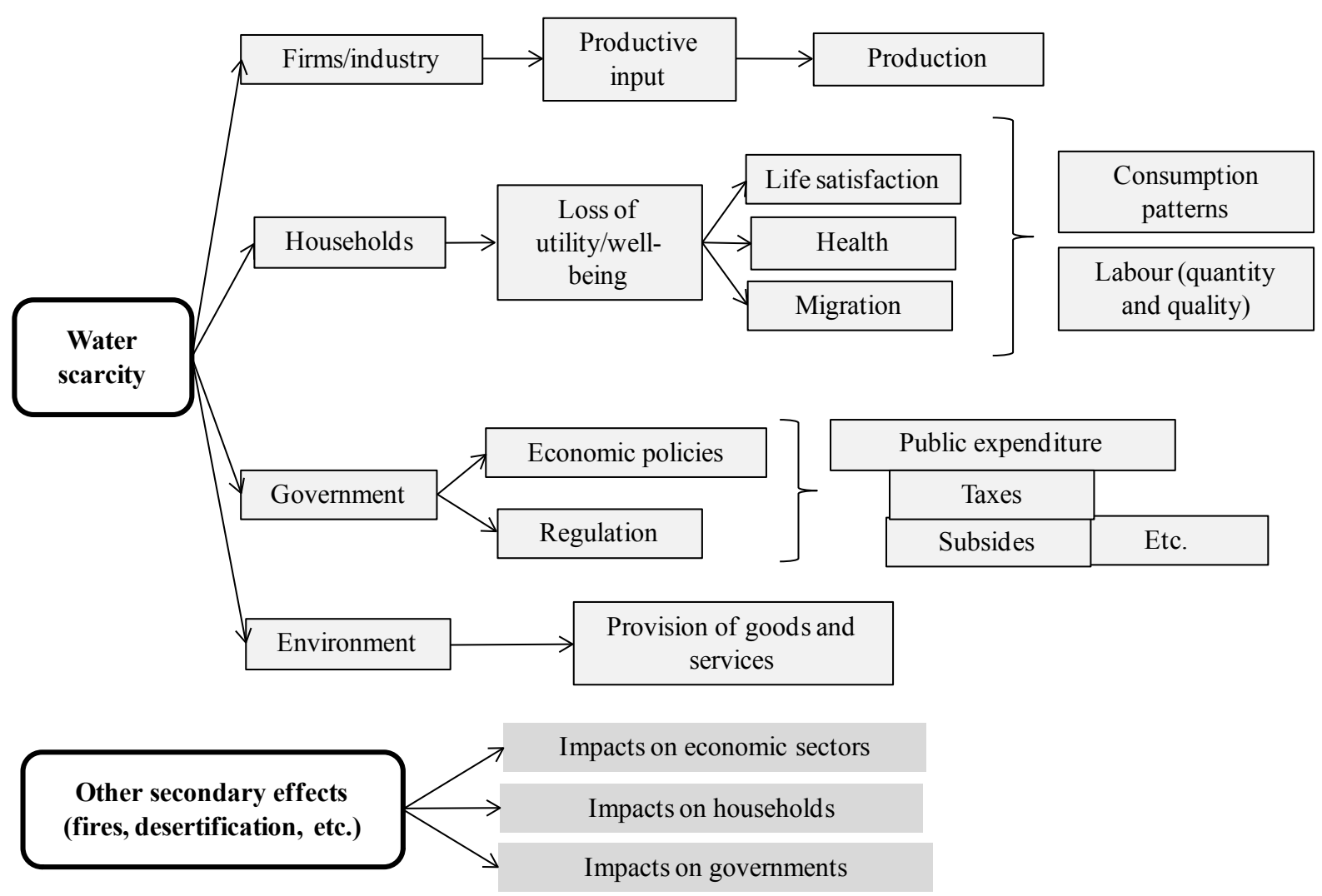

Fig. 1. Economic impacts of droughts.

Fig. 1 differentiates between two types of impacts. The first type of impact is related to how a lack of water affects different economic agents such as industry, households, government and the environment. The second type of impact refers to the secondary effects of a drought from fires, 
desertification, migrations, etc. Each of these secondary effects needs a specific framework of economic analysis beyond the effects of the lack of water on the economic systems. Most existing empirical studies on drought focus only on one type of impact, and do not attempt to assess all of the impacts on different economic agents (industry, households, environment etc.) within an integrated framework.

Several methodological approaches are used to assess impacts in the existing studies on drought impacts. These approaches include: computable general-equilibrium (CGE) modelling and inputoutput (I-O) analysis; partial equilibrium approaches; econometric methods; and more qualitative based assessments. For recent compilation of the most important literature on them see Meyer et al. (2013), and for specific reviews for droughts see Dudu and Chumi (2008), Ding et al. (2010), Logar and van den Bergh (2013) and Young and Loomis (2014). The review by Logar and van den Bergh (2013) concluded that market valuation techniques (i.e. market prices, production function, avoided costs, replacement or repair costs) are the most suitable methods for assessing direct tangible costs. Moreover, despite acknowledged limitations of these methods (Logar and van den Bergh, 2013; Meyer et al., 2013), it is generally recognised that economy-wide approaches, such as CGE analysis or I-O analysis, are the most complete methods, because they take all sectors of the economy into account and are therefore capable of capturing both direct and indirect effects. However, the application of these approaches is often restricted by available data, and as discussed below, there is a need to make various adjustments to these models to account for some of the specific characteristics of droughts.

Table 1 provides an overview of selected empirical studies that have assessed the economic impacts of droughts. The table identifies the cost categories included in the analysis, and the methods applied to derive the estimates.

Table 1. Selected empirical studies on the costs/impacts of droughts 


\begin{tabular}{|c|c|c|}
\hline Cost category & Method & Reference \\
\hline Direct & $\begin{array}{l}\text { Direct assessment of costs on } \\
\text { companies or sectors }\end{array}$ & $\begin{array}{l}\text { Benson and Clay (1998) } \\
\text { COPA-COGECA (2003) } \\
\text { Rijkswaterstaat (2004) } \\
\text { Corti et al. (2009) } \\
\text { Christian-Smith et al. (2011) } \\
\text { DEFRA (2013) }\end{array}$ \\
\hline & Damage functions & $\begin{array}{l}\text { Corti et al. }(2009,2011) \\
\text { Jenkins }(2013)\end{array}$ \\
\hline & $\begin{array}{l}\text { Market valuation (WTP, market } \\
\text { prices, production function, } \\
\text { avoided costs, replacement or repair } \\
\text { costs, etc.) }\end{array}$ & $\begin{array}{l}\text { Easterling and Mendelsohn (2000) } \\
\text { Grafton and Ward (2008) }\end{array}$ \\
\hline & $\begin{array}{l}\text { Integrated Assessment Analysis, } \\
\text { Biophysical-Agroeconomic } \\
\text { Models }\end{array}$ & $\begin{array}{l}\text { Kulshreshtha and Klein (1989), } \\
\text { Rosenberg (1993) } \\
\text { Holden and Shiferaw (2004) } \\
\text { Fischer et al. (2005) }\end{array}$ \\
\hline & $\begin{array}{l}\text { Integrated Assessment Analysis, } \\
\text { Hydrological-Economic } \\
\text { Models }\end{array}$ & $\begin{array}{l}\text { Booker et al. (2005), } \\
\text { Ward et al. (2006) } \\
\text { Grossmann et al. (2011) }\end{array}$ \\
\hline $\begin{array}{l}\text { Indirect and economy- } \\
\text { wide }\end{array}$ & CGE & $\begin{array}{l}\text { Islam (2003) } \\
\text { Horridge et al. (2005) } \\
\text { Rose and Liao (2005) } \\
\text { Berrittella et al. (2007) } \\
\text { Boyd and Ibarrarán (2009) } \\
\text { Pauw et al. (2010) } \\
\text { Wittwer and Griffith (2010) }\end{array}$ \\
\hline & Supply Input-output & $\begin{array}{l}\text { Davis and Salkin (1984) } \\
\text { Pérez y Pérez and Barreiro-Hurlé } \\
\text { (2009) }\end{array}$ \\
\hline
\end{tabular}




\begin{tabular}{|c|c|c|}
\hline & & Freire-González (2011a) \\
\hline & & Howitt et al. (2014) \\
\hline & Adaptative regional Input-output & Jenkins (2013) \\
\hline & Inoperability Input-output & Santos et al. (2014) \\
\hline & & Pagsuyoin and Santos (2015) \\
\hline & Macroeconometric & Salami et al. (2009) \\
\hline \multirow[t]{4}{*}{ Intangible } & Contingent valuation & Pattanayak and Kramer (2001b) \\
\hline & Choice modelling & Hensher et al. (2006) \\
\hline & Cost-based methods & Banerjee et al. (2013) \\
\hline & Life satisfaction analysis & Carroll et al. (2009) \\
\hline \multirow[t]{5}{*}{ Risk mitigation } & Cost of implementation & Michelsen and Young (1993) \\
\hline & & Woo (1994) \\
\hline & & Pattanayak and Kramer (2001a,b) \\
\hline & & Morton et al. (2005) \\
\hline & & Grafton and Ward (2008) \\
\hline
\end{tabular}

Source: own elaboration from Meyer et al. (2013).

\section{DISTINGUISHING DROUGHTS AS A TYPE OF NATURAL HAZARD}

There are a number of important characteristics of droughts which, from an economic perspective, distinguish them from other natural hazards.

\subsection{Impacts on capital and economic growth}

Droughts do not usually cause damage (or cause little damage) to the physical capital stock (or physical assets), so the public and private stock of capital is not usually affected by a drought. This is 
an important distinguishing feature of droughts as the main economic impact of most natural hazards -such as earthquakes, hurricanes or floods- involves damage to capital, such as machinery, buildings and other physical assets. That said, of the relationship between drought and physical capital has to be considered carefully as some damage to physical capital may occur over the longer-term, such as from saltwater intrusion leading to land degradation, building damage due to soil subsidence and damage to ecosystems from excessive groundwater pumping or abstractions. ${ }^{1}$

The damage to human capital in a drought is also very different than it is for other natural hazards. Droughts experienced in industrialised countries have not typically resulted in sustained damage to human capital. However, this is not always the case for the least developed countries (LDCs), where droughts can be associated with malnutrition and loss of life. ${ }^{2}$ Where this occurs, it impacts on the human capital potential of an economy, which in turn can adversely impact on long-term economic development.

For these reasons, in the short-term at least, droughts do not generally affect the production capacity of an economy. That is, the productive capacity of an economy should, in many circumstances, remain similar both before and after a drought event. Accordingly, unlike many other natural hazards, in developed economies droughts should not affect the long-term growth possibilities of an economy. ${ }^{3}$

\footnotetext{
${ }^{1}$ See Corti et al. (2009) who examined the link between past drought events and annual variations in damages to buildings due to soil subsidence in France. They found a link between soil moisture extremes and related building damages. However, this is a long-term process, and there is no a reconstruction process after a drought like after other natural hazards, since damages are not that evident.

${ }^{2}$ This is often captured in terms of the water-energy-food nexus (see http://www.unwater.org/topics/water-food-and-energynexus/en/).

${ }^{3}$ Logar and van den Bergh (2013) state that droughts usually cause fewer visible infrastructural damages than other hazards, except for damages from ground subsidence and fires.
} 
This also implies that there is no post-disaster reconstruction process following droughts. ${ }^{4}$ Economic assessments of the costs/impacts of other natural hazards generally incorporate these positive impacts which, in some cases, can counteract some of the immediate negative impacts of the damage. Some studies show that post-disaster reconstruction and relief payments can generate a boom in the economy offsetting the hazard losses (Albala-Bertrand, 1993). In addition, replacement of capital provides opportunity for productivity-raising innovations (Mysiak and Markandya, 2009). An implication of this point is that assessment methods which focus on assessing demand side impacts, by an expansion/contraction of final demand on the economy (like for instance an expansion of the public sector spending), following a natural hazard may not be appropriate when analysing droughts given the limited expected change in final demand.

\subsection{Direct impacts only on specific sectors}

The direct economic impacts of droughts in terms of indicators such as changes in productive output , value added, wealth or employment arise only for those economic activities that use water as a critical or important input to their production processes. Although a drought can have important ecological, socioeconomic and cultural impacts, in production terms a drought primarily represents a situation of interrupted supply of a key input for those production processes which require it. The most important of these production processes are typically agriculture, energy production and public water supply. Manufacturing processes and service activities that do not use significant volumes of water are therefore unlikely to experience significant direct impacts of a drought, except in extreme cases.

\footnotetext{
${ }^{4}$ By reconstruction we are referring to the repair of existing physical capital to its pre-drought productive potential. However, we recognise that a drought can often result in new investments in capital and other initiatives to protect against future droughts. A reviewer usefully points us to the example of the investments made by the Australian Government following the Millennium Drought.
} 


\subsection{Importance of temporality}

Droughts have a specific temporality, and this factor is usually more important than in other natural hazards when assessing economic impacts. Two important characteristics of droughts have an effect on the economic impact: the length and the severity. While for most other natural hazards severity is the key variable, the consideration of both combined is relevant when assessing the economic impacts of a drought. In this respect, it is important to distinguish between the short-term and the long-term economic impacts of drought. The latter involve behavioural responses, including changes in expectations of economic agents that produce deeper changes in economic systems. Given the sequential nature of a drought incorporating the temporal aspect is an important component of any analytical framework for assessing impacts.

\subsection{Policies and economic impacts}

An important feature of droughts is that the economic impacts depend significantly on long-term and short-term policy choices.

Long-term policy decisions relate to water resources and drought management planning, including public and private investments in water storage and production capacity. As discussed in more detail in section 5, long-term policy decisions affect the level and composition of the hydraulic stock of capital which has implications for the magnitude of the economic impacts. LDCs or countries with low control of water resources often lack adequate hydraulic infrastructure, or institutional capacity, and are therefore more vulnerable to drought. 
Short-term policy decisions relate to the management and operational decisions taken during a drought such as which users should be subject to water restrictions, how much water should be restricted and when to introduce restrictions. The relationship between different short-term policy decisions and economic impacts is considered in section 6.

Policy decisions or choices are not just those of government but also include all other stakeholders, including water companies, environmental and economic regulators, industrial users and household consumers. Each of these entities has the ability, albeit in different capacities, to make management and usage choices which can affect the supply-demand balance.

\section{SOURCES OF ECONOMIC IMPACT OF DROUGHTS}

For a given level of water demand, the total water availability in a region, either for the environment, the society or for the economic system is determined by two factors:

- Climate conditions, principally rainfall, dryness or humidity, temperature, etc.

- The capacity of that the region to call upon other sources of supply. This includes water: that has been previously stored in groundwater, dams and reservoirs; can be imported/transported from other areas/regions; or 'produced' such as through desalination facilities or even recycling facilities.

A distinction can be made between the availability of 'green water' and 'blue water'. In simple terms, green water is defined as precipitation stored in the soil or is temporarily stored on the top of the soil and vegetation. Green water is therefore especially important for crop growth. ${ }^{5}$ In contrast, blue water

\footnotetext{
${ }^{5}$ Specifically, 'green water' has been defined as: "the precipitation on land that does not run off or recharge the groundwater but is stored in the soil or temporarily stays on top of the soil or vegetation. Eventually, this part of precipitation evaporates or transpires through plants. Green water can be made productive for crop growth (although not
} 
has been defined as: "fresh surface and groundwater, in other words, the water in freshwater lakes, rivers and aquifers". ${ }^{6}$ Blue water also includes water captured and stored in artificial dams and reservoirs.

Climate conditions directly impact some specific economic activities, particularly those related to agriculture that need green water, through a reduction in its availability. However, other activities may not be directly affected by a shortage of green water. Stored water can mitigate the impact on agriculture and the other green-water reliant activities insofar as they can rely on water supply systems to maintain their production levels, to a greater or lesser extent. At the same time, climate aspects, like humidity, temperature, but especially rainfall conditions, can determine stored water levels so they can affect economic activities in posterior periods, delaying the impacts of droughts. This relationship between storage and the production capacity of water and economic impacts is further developed below.

\subsection{A green water drought}

In terms of impacts, the initial stage of a drought generally only directly impacts those sectors that use green water (mainly agriculture) ${ }^{7}$. If there are sufficient blue water reserves, and flexibility ${ }^{8}$ in how such reserves are used, there should not be any significant economy-wide impacts of a drought. This is because during this initial stage, even if the green water drought intensifies (in duration and/or

\footnotetext{
all green water can be taken up by crops, because there will always be evaporation from the soil and because not all periods of the year or areas are suitable for crop growth)" http://waterfootprint.org/en/water-footprint/glossary/.

${ }^{6}$ Ibid.

${ }^{7}$ Inland water transport, gardening, some sports like golf, etc. would also likely be directly affected by a green water drought.

${ }^{8}$ Flexibility refers to the capacity of the system to produce or access different sources of blue water, or to transport blue water resources, within a reasonable timeframe and at relatively low cost.
} 
intensity), other economic activities and sectors are able to call on blue water to maintain their activities. However, over time the blue water reserves will start to reduce, and other existing water supply systems, such as desalination plants, may need to intensify their activity, in order to maintain the same water supply to all the economy. Demand-side measures may also be taken (either voluntary or enforced by regulators) which could have the effect of mitigating the reduction in blue water reserves.

After this initial stage of a drought, other sectors of the economy may, albeit to different degrees, be indirectly affected due to the direct effect on (non-irrigated) agriculture in the first stage. This is because if agriculture reduces its production in the short-term, this could increase prices (or reduce salaries or profits, or a combination of both, depending on the market structure, among other factors). ${ }^{9}$ This may have impacts on households, public administrations, imports, exports and other activities due to the interdependencies across the economic systems.

Green water drought events can be measured and even quantified through several indicators, most of them related to climate conditions such as precipitation, wind, humidity, temperature, etc. Jenkins (2012), who analyzed the economic impacts of droughts, used the Standardized Precipitation Index (SPI) from McKee (1993) which provides a measure of the deviation in precipitation from average conditions over time. Although these indicators have a high correlation with the economic impact from 'green water' sources, they can lead to biases when dealing with 'blue water' impacts and other factors such as short-term policy decisions. There are many other drought indicators, and a useful recent review can be found in Bachmair et al (2016).

\subsection{A blue water drought}

\footnotetext{
${ }^{9}$ The impact of imports is likely to be particularly important for some economies, and may mitigate the impact of price increases.
} 
Blue water can potentially totally, or partially, offset the impacts of a drought if it is properly managed before, during and after a drought situation. This means that authorities have some level of control over the impacts on economic activities and households, especially when considering public blue water. However, there are budgetary and institutional constraints that can limit its control.

There is a temporal link between a green water drought and a blue water drought. A prolonged and intense green water drought is likely to involve the existing reserves of blue water being reduced over time. In situations where there is a high level of blue water reserves a prolonged green water drought may have no significant economy-wide economic impact, because blue water is sufficient to satisfy demand of the region or because agriculture is able to exploit blue water to compensate for green water drought.

Conversely, in settings where there is a low level of blue water reserves there is likely to be a much closer connection between a green water drought and a blue water drought. Specifically, in settings where there is limited blue water available, a green water drought is likely to have a direct and immediate impact on all water-intensive economic sectors, and indirectly on the wider economy. This type of situation is more likely to arise in regions where the level of blue water availability is limited, such as the case in many LDCs.

\section{THE ROLE OF HYDRAULIC CAPITAL ON THE ECONOMICS OF DROUGHTS}

Water policy planning or long-term water policy decisions affect the level and composition of capital, mainly hydraulic public and private capital. In this section we show how the level and composition of hydraulic capital plays an important role in determining the magnitude and distribution of economic 
impacts associated with drought. Hydraulic capital is defined as durable assets used in the production, storage, recycling, interconnection or transportation of water for public or private supply (examples include dams and reservoirs, desalination plants, private and public water storage systems).

\subsection{Optimal level of blue water}

It follows from the preceding discussion that the economic impact of droughts can depend significantly on the amount of blue water availability, which in turn depends on hydraulic capital public and private. In the extreme, it is possible to imagine a situation where there is an infinite amount of blue water available, because of extensive storage, reuse or desalination facilities, and the economic impacts of a green drought are limited. However, investments in blue water availability are not costless, and can impose significant costs on society.

A range of factors need to be considered in determining the appropriate level of hydraulic capital. First, there are cost considerations, including investment costs, maintenance costs, operational, environmental and other external costs. Second, there are questions about the composition of the hydraulic capital stock: should it involve storage facilities, pipelines or other flexibility mechanisms such as a water grid- or investments in desalination and other production facilities such as recycling facilities. Different costs are associated with each of these options. Third, the level and composition of hydraulic capital should be calibrated to climate factors such as the likelihood, expected frequency and severity of drought events. Fourth, there are social factors to consider such as the need and use of water in a specific society, ${ }^{10}$ and the social benefits of having more water available.

\footnotetext{
${ }^{10}$ This might be captured in the concept of a given society's 'tolerability' for drought or water scarcity - i.e.: the willingness of a society to incur water shortages or restrictions.
} 


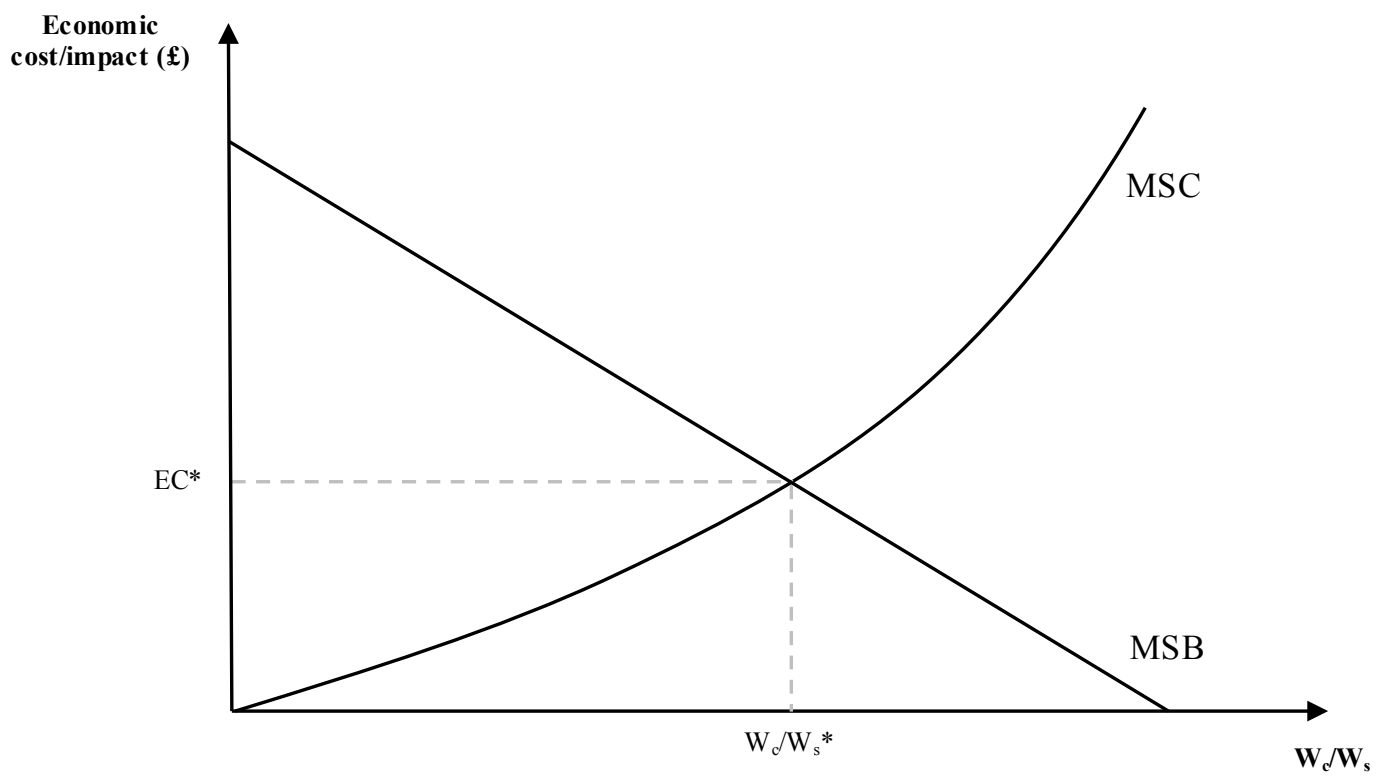

Fig. 2. Optimal level of blue water

Fig. 2 illustrates the relationship between economic cost/impact of blue droughts and the amount of hydraulic capital. Similar approaches to the cost-benefit analysis of adaptation measures in water issues are provided by Guiu et al. (2015), Rietveld (2011) and Jonkman et al. (2004). $\mathrm{W}_{\mathrm{c}}$ is the total water storage and production capacity of a region (blue water). $\mathrm{W}_{\mathrm{s}}$ is a measure of socio-cultural, institutional and technological factors that affect the water needs of the socioeconomic system of a region. The quotient $\mathrm{W}_{\mathrm{c}} / \mathrm{W}_{\mathrm{s}}$ is therefore an indicator of the resilience of the region to droughts. ${ }^{11}$

Marginal social costs (MSC) include both private and public hydraulic investment costs, operation and maintenance of infrastructure, and external costs, such as environmental costs. Marginal social benefits (MSB) include social benefits in terms of water availability of the economic system, and other external benefits. The optimum level of water storage and production for a particular region is determined by the intersection of these curves. In fig.2, the optimal level $\left(\mathrm{W}_{\mathrm{c}} / \mathrm{W}_{\mathrm{s}}{ }^{*}\right)$, involves a cost of (EC*), which the point where the MSC and the MSB intersect. At points beyond the intersection of the MSB and MSC curves, the MSB associated with additional resilience is not efficient, having

${ }^{11}$ Where resilience is defined as the capacity of a society to endure a drought event with impacts lying within a tolerable range. 
regard to the marginal social costs. To take a concrete example, there may be some additional incremental social benefit in terms of reducing the economic cost of drought if a region invested in a desalination plant. However, this additional marginal social benefit in terms of reduced cost of a drought is outweighed by the additional incremental social cost associated with building and operating the facility, including environmental costs.

MSC has been drawn as an exponential function since an increase of the overall capacity implies the development of more expensive alternatives with an increase of the maintenance and operation cost of existing and new sources. It also reflects the fact that environmental impacts typically also increase as the hydraulic capital stock increases.

$\mathrm{W}_{\mathrm{s}}$ is unique for each region and time. This model also allows for the possibility of improving $\mathrm{W}_{\mathrm{s}}$, so that reductions in water demand would lead to lower overall costs and increased benefits with the same water storage and production capacity. Higher income levels and technological progress would also shift the MSC curve to the left and change its shape, assuming lower costs levels reaching the same resilience levels. In addition, because investment costs, maintenance costs, operational costs and other environmental costs grow exponentially, measures which reduce $\mathrm{W}_{\mathrm{s}}$ such as demand management initiatives can increase resilience and reduce the economic impacts of droughts for a lower MSC. Factors that increase the vulnerability of a region to drought, like changes in the climate, shift the MSB curve to the right; that is, an increase of the relative water capacity is needed to obtain the same benefit. Risk aversion also affects the MSB curve. ${ }^{12}$

\subsection{Link between hydraulic stock level and economic impact of droughts}

\footnotetext{
${ }^{12}$ An empirical application of the marginal cost curves applied to water scarcity adaptation issues can be found, for instance, in McKinsey (2009).
} 
The level and composition of hydraulic capital in a region is a key factor that can influence the economic impact of droughts. In an extreme case where there is no hydraulic capital, even a small drought in terms of intensity would typically have an economic impact. Conversely, if a region has a very high level of hydraulic capital, then a drought will likely only have a significant impact on agricultural systems that depend on green water (assuming there is no flexibility or capacity to obtain blue water). The relationship between the intensity of the drought, the level of hydraulic capital and economic impact is shown in Fig. 3 below.

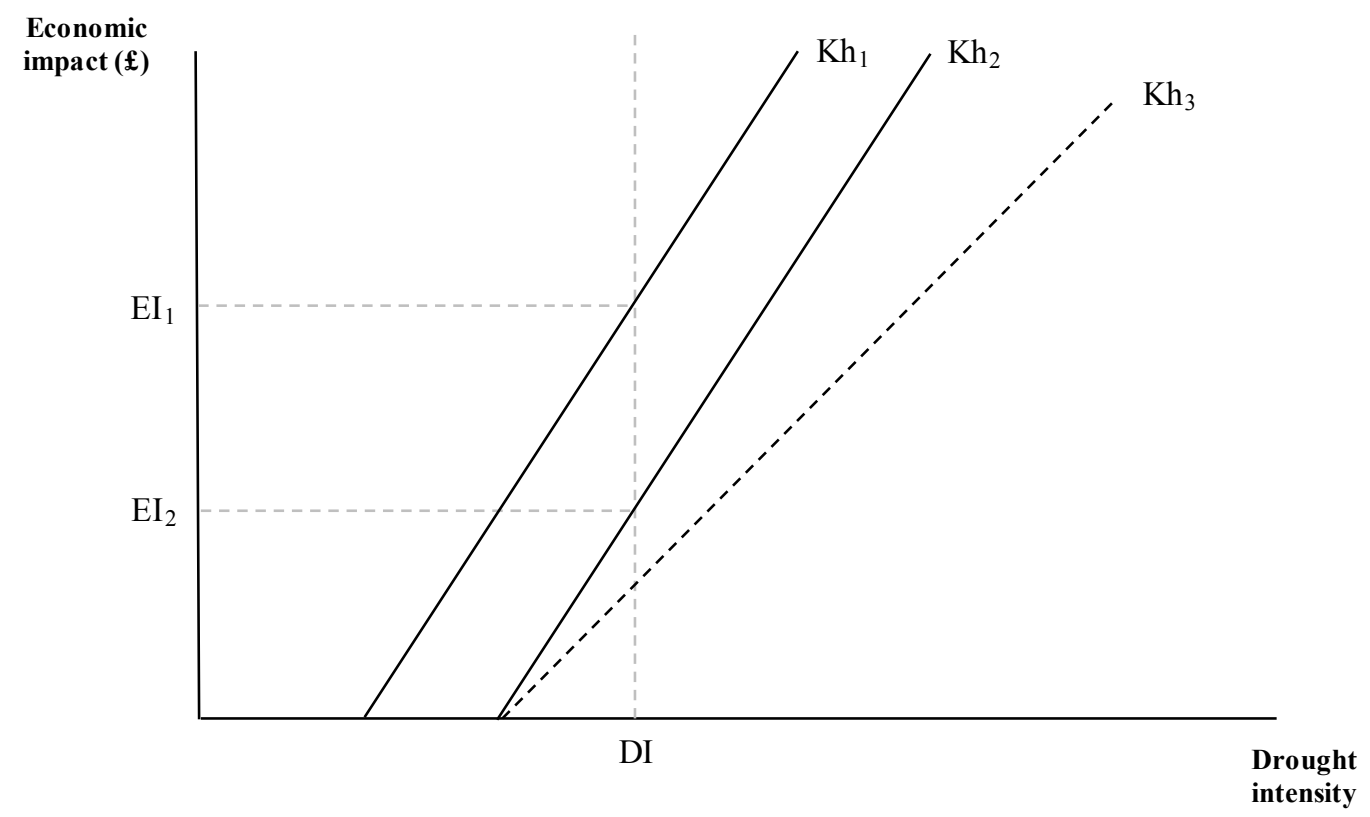

Fig. 3. Effects of hydraulic stock of capital composition on 'blue water' economic impact of droughts

Fig. 3 shows two different levels of hydraulic capital stock $(\mathrm{Kh})$ for a specific region. $\mathrm{Kh}_{1}$ and $\mathrm{Kh}_{2}$ have exactly the same composition but involve different level of investment, while $\mathrm{Kh}_{3}$ has a different composition. In this figure because $\mathrm{Kh}_{1}<\mathrm{Kh}_{2}$, this means that the direct economic impact for a drought of intensity (DI) will result in a higher economic impact if the hydraulic level of capital is at $\mathrm{Kh}_{1}$ as compared to if the level of hydraulic capital is $\mathrm{Kh}_{2}$ (i.e.: $\mathrm{EI}_{1}>\mathrm{EI}_{2}$ ). The curve $\mathrm{Kh}_{3}$ has a different composition of hydraulic capital stock that makes the economic system more resilient to droughts, such that a drought of intensity (DI) will have an even lower economic impact. Put differently, the latter curve has a lower elasticity impact of drought intensity. 
Each region has their specific curves depending on climate characteristics, economic structure and other behavioral and cultural factors. The precise functional form will depend on the composition and characteristics of the hydraulic capital available to deal with drought. However as shown in fig. 2 , the accumulation of hydraulic capital is not costless, and the optimal level of capital stock will need to balance the MSC against the MSB.

Long-term policy-making in this context involves the development of programs, plans and strategies to manage water resources, in order to make the system more resilient to droughts. They can involve supply side policies, like investments in hydraulic capital or changes to water trading arrangements, or demand side initiatives, like awareness campaigns.

\section{SHORT-TERM POLICIES AND ECONOMIC IMPACT OF DROUGHTS}

Short-term policy decisions in this framework are those decisions taken during the drought event. Hydraulic capital stock level and composition is fixed, and is assumed not to change in the short-term. It follows that short-term decisions are mainly related to the use and management of existing blue water resources during a drought event.

Governments, water suppliers or even users may decide (either voluntarily or mandatorily) to not use all of the potentially available blue water, but introduce some form of restriction or rationing in order to maintain the supplies of blue water. These short-term operational choices as to the extent, scope and duration of blue water restrictions are important in assessing economic impacts as they determine who is affected (i.e.: which economic sectors), how long they are affected for, and by how much supply is restricted. 


\subsection{Dynamic economic effects of droughts on the productive system}

Fig. 4 shows, in a simplistic way, how sequential short-term decisions on the use and management of existing blue water resources can interact with the productive system during a drought, which in turn, determines the economic impact of a drought. As noted, in the short-term the hydraulic capital stock is fixed, so policy-makers can only control the economic impact by managing that hydraulic capital as shown.

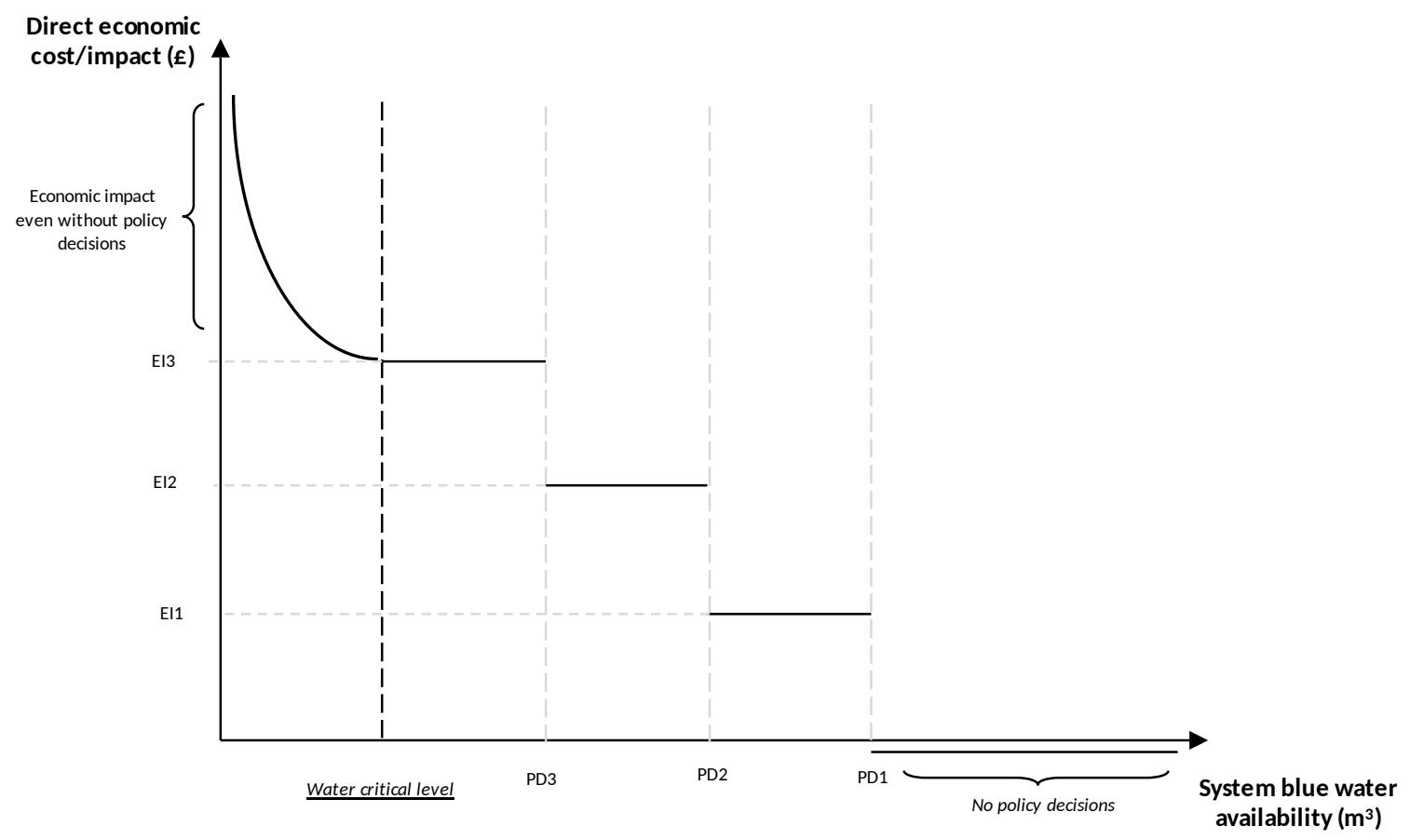

Fig. 4. Economic impact curve of droughts on economic agents

Fig. 4 can be interpreted as follows. At the beginning of a drought (points to the right of PD1), water systems -supported by hydraulic capital- have sufficient reserves. At these points a drought will not give rise to any economic impacts except for agriculture and other green water reliant activities which 
have a limited ability to access blue water. ${ }^{13}$ However, once the drought intensifies and the blue water reserves reach point PD1, a policy decision to reduce available water supplied (by water restrictions being imposed on some industries/agents) of blue water results in some economic impact (EI1). After that, although the available blue water continues to reduce, non-green water reliant economic agents will not notice another impact until after the second policy decision (PD2). At this point water is further restricted resulting in a higher direct economic cost/impact (EI2).

The central point is that the economic impacts of drought follows a discrete step-change curve, where the steps -and associated economic impacts- are determined by the frequency and magnitude of policy decisions regarding the actual amount of blue water that will be released. An important point to note is that blue water includes public hydraulic capital and private blue water (private storage systems like holes, etc.). This means that private economic agents also manage some blue water resources, assuming an economic impact with micro-steps inside this general framework.

It follows that the capacity of substitution of water can increase or reduce the expected economic impact of a drought, affecting the resilience of a sector. Some technologies can reduce the use of water through water efficiency improvements or technological change. By making capital investments which adopt more efficient technologies (e.g. new irrigation or cooling technologies) some industrial actors can reduce their overall water use . In the long term a high recurrence of droughts could affect the incentives for the development and adoption of new more efficient technologies across industry sectors. However, the economic and resource use effects of improvements in water efficiency is largely unexplored, and is an area which needs to be further developed. In particular, as has been seen in energy economics, improvements in efficiency could lead to a great use of the resource; the socalled 'rebound' effect. ${ }^{14}$

\footnotetext{
${ }^{13}$ However, as noted, even for these activities the impact can depend on -or can be offset by- the water supply or water abstraction from the system depending on the amount, composition and flexibility of hydraulic capital.

${ }^{14}$ See Khazzoom (1980), Greening et al. (2000), Freire-González (2011b).
} 


\subsection{The scope for short term management of droughts}

In fig. 4 shows that the scope for policy-makers and other private actors to implement short-term drought management measures is determined by distance between the first policy decision (PD1) to the water critical level (WCL). The size of this range is determined by the amount of blue water. Fig. 5 shows two different possible ranges for management decisions during a drought situation. It highlights that the capacity for authorities and other private actors to implement drought management options increases with a greater availability of fixed hydraulic capital.
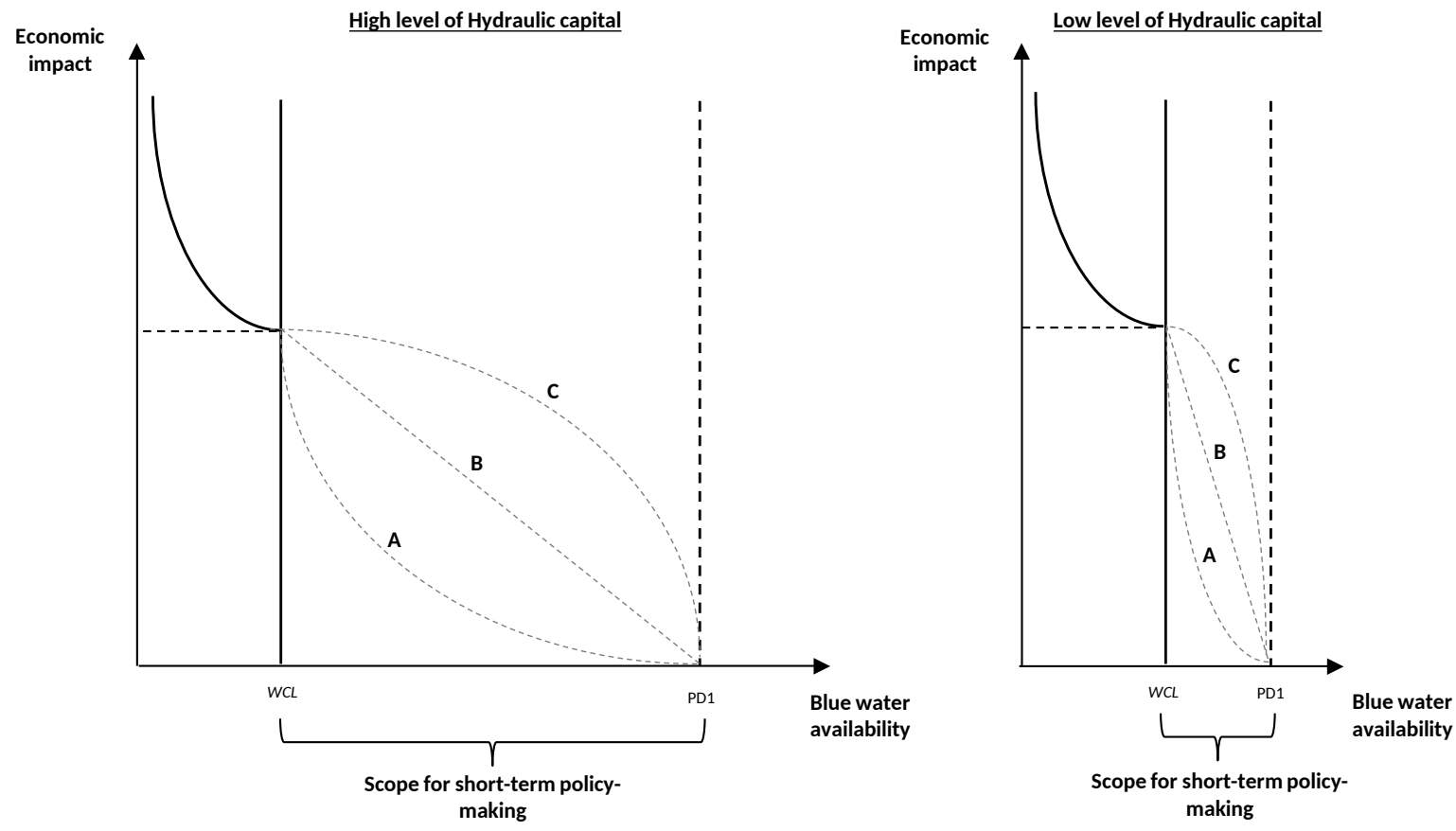

Fig. 5. Short-term policy-making process during a drought situation and economic impact

Fig. 5 also shows that for a given level of hydraulic capital there are different short-term management trajectories (e.g.: A, B, C, etc.). It also shows that the range over which management options can be exercised is greater if hydraulic capital stock level is higher. 
Path $A$ represents an 'optimistic' management path. It starts with low-levels of restrictions on water availability on the basis of an expectation of an improvement in climate conditions, but after a certain point the water restrictions increases at a higher rate as the drought intensifies towards the water critical level (WCL). In contrast, path $C$ shows a 'pessimistic' management path which imposes more stringent water restrictions early, which has a more immediate economic impact.

\section{CONCLUSIONS}

A number of conclusions emerge from this research which should guide the development of a richer analytical framework for assessing the economic impacts of droughts. First, we have identified two sources of economic impacts of droughts. The first source is related to the concept of 'green water' and is mainly determined by climate conditions. As we have shown, in the first stage of a drought will be expected to have a significant and direct impact mainly on agricultural and other green-water reliant industries. A second source of impact comes from choices made in relation to the water storage, interconnection and production capacity. This is the concept of 'blue water'. The economic impacts from this source can directly affect all sectors of the economy. While a blue water drought can be related to climate conditions, it need not be, and it is possible to develop sufficient blue water reserves to sustain an economy through a prolonged green water drought. However, investments in hydraulic capital involve costs, and a given society needs to determine what is the optimal amount of such capital to ensure a desired level of system resilience.

A second conclusion is that although droughts are correctly classified as a type of natural hazard, they have a number of characteristics that differentiate them from other natural hazards in economic terms. Important among these is the critical role of long-term and short-term policy decisions. There is considerable scope for policy choices in relation to blue water to mitigate the economic impacts from this drought source. For example, policy choices in relation to the amount of storage capacity, 
desalination facilities, or in terms of public awareness can be important in reducing the exposure of an economy to drought impacts. However, as we have shown, many of these policy choices are not costless, and the optimal level of blue water availability (i.e.: resilience) is likely to reflect choices about the level of resilience that a society is prepared to pay for and tolerate. Moreover, policy decisions taken within a period of drought -for example, when introducing restrictions, who they should apply to and how long they should last- can be significant in terms of conditioning the economic impacts of drought.

Third, consideration of the specific characteristics of drought as a natural event, and the particular role that policy choices can have on the impacts of a drought, requires a richer analytical framework for assessing the economic impact of drought. If the factors identified in this paper are not taken into account then there is a risk that the estimates of economic impact of drought may be biased. As emphasised, any assessment of economic impact should take account of the two sources of drought identified in this paper (green water and blue water), each of which can result in different economic impacts. Equally important, economic assessments have to account for policy-decisions -either by public administrations, water suppliers or private actors- and not automatically assume proportional losses (or other functional forms) depending on the climate conditions or others. The existence of blue water requires that scenario-based assessment of economic impact take account of policy decisions. In the framework we have developed, long-term policies are, in part, related to the quantity and composition of infrastructure provided to guarantee water supply systems (i.e.: hydraulic capital), while short-term policies are those measures and decisions taken during the drought, mainly related to the water use of specific agents, as capital stock cannot change in the short term.

The framework we have outlined is potentially useful for a wide range of actors (policy-makers, water board managers and regulators, water companies and economists) and in a range of different economic contexts (both developed and less developed economies). For economists engaged in assessing economic impacts, our hope is that by setting out the different elements to consider it will provide some consistency to the approaches used to derive empirical estimates of the economic 
impacts of drought across jurisdictions and over time. Similarly, it is our hope that the framework will provide policy-makers, water board managers/regulators, and water companies with a framework to assess the costs and trade-offs associated with different short-term and long-term actions, including making investments in hydraulic capital.

The aim of this research is to provide a conceptual framework for analysis and not to detail how the framework and concepts might be applied in a quantitative way in practice. While we consider that the framework could readily be applied to assess the economic impacts of an actual or expected drought event, such an empirical analysis is not within the scope of the current paper. Further research will seek to apply the framework to estimate expected drought impacts under a range of climate and policy scenarios. An important part of that analysis is to situate the assessment of economic impacts within a cost benefit framework which takes account of factors such as resilience and the tolerable levels of water disruption in a society; the potential social benefits and costs of investments in hydraulic capital and improved water management; and the implications of different scenarios about blue and green water levels.

A number of the elements identified in the framework presented in this paper could benefit from further inquiry. Among these: research which provides empirical estimates of the economic impact curves or MSC, MSB curves; an improved understanding of the policy and societal measures to reduce social need of water (Ws); more empirical evidence of how households behave and other actors behave during drought -and extreme drought- situations; ${ }^{15}$ and finally, some analysis of the possible adaptation paths for policy-making, given future climate conditions and the importance of green water and blue water for the economic and social systems.

\footnotetext{
15 There is evidence on how irrigators in Australia adapted their behavior during the Millennium Drought. Kirby et al. (2014) identify measures such as input substitution, crop mix changes, water trading and technology improvements. Wheeler et al. (2014) focus on the role of water markets and water trading as an adaptation method for irrigators.
} 


\section{ACKNOWLEDGEMENTS}

This research is part of a NERC funded project: MaRIUS project: Managing the Risks, Impacts and Uncertainties of droughts and water Scarcity (NE/L010364/1).

\section{REFERENCES}

Albala-Bertrand, J.M., 1993. Natural disaster situations and growth: A macroeconomic model for sudden disaster impacts. World Development 21(9), 1417-1434.

Bachmair et al (2016). Drought indicators revisited: practice in monitoring and early warning and the link to drought impacts. WIREs Water 3, 516-536.

Banerjee, O., Bark, R., Connor, J., Crossman, N.D., 2013. An ecosystem services approach to estimating economic losses associated with drought. Ecol. Econ. 91, 19-27.

Benson, C., Clay, E., 1998. The impact of drought on Sub-saharan African economies. World Bank, Washington D.C.

Berrittella, M., Hoekstra, Y.A., Rehdanz, K., Roson, R., Tol, R.S.J., 2007. The economic impact of restricted water supply: A computable general equilibrium analysis. Water Res. 41, 1799-1813.

Booker, J.F., Michelsen, A.M., Ward, F.A., 2005. Economic impact of alternative policy responses to prolonged and severe drought in the Rio Grande Basin. Water Resour. Res. 41(2), W02026.

Boyd, R., Ibarrarán, M.E., 2009. Extreme Climate Events and Adaptation: An exploratory analysis of drought in Mexico. Environmental and Development Economics 14, 371-395.

Bronswijk, J.J.B., 1989. Prediction of actual cracking and subsidence in clay soils. Soil Sci. 148, 8793.

Carroll, N., Frijters, P., Shields M.A., 2009. Quantifying the costs of drought: new evidence from life satisfaction data. J. Popul. Econ. 22, 445-461. 
Christian-Smith, J., Levy, M., Gleick P.H., 2011. Impacts of the California Drought from 2007 to 2009. Pacific Institute.

COPA-COGECA, 2003. Assessment of the impact of the heat wave and drought of the summer 2003 on agriculture and forestry, Committee of Agricultural Organisations in the European Union and the General Committee for Agricultural Cooperation in the European Union.

Corti, T., Muccione, V., Kollner-Heck, P., Bresch, D., Seneviratne, S.I., 2009. Simulating past droughts and associated building damages in france. Hydrol. Earth Syst. Sci. 13, 1739-1747.

Corti, T., Wüest, M., Bresch, D., Seneviratne, S.I., 2011. Drought-induced building damages from simulations at regional scale. Nat. Hazards Earth Syst. Sci. 11, 3335-3342.

Davis, H.C., Salkin, E.L., 1984. Alternative approaches to the estimation of economic impacts resulting from supply constraints. The Annals of Regional Science 18(2), 25-34.

DEFRA, 2013. The impacts of drought in England. R\&D Technical Report WT0987/TR

Ding, Y., Hayes, M. J., Widhalm, M., 2010. Measuring Economic Impacts of Drought: A Review and Discussion. Papers in Natural Resources 196.

Dudu, H., Chumi, S., 2008. Economics of Irrigation Water Management: A Literature Survey with Focus on Partial and General Equilibrium Models. Policy Research Working Paper 4556. The World Bank.

Easterling, W., Mendelsohn R., 2000. Estimating the economic impacts of drought on agriculture, in: Drought: A Global Assessment, edited by: Wilhite, D. A., 1, 256-268, London/New York: Routledge. Fischer, G., Shah, M., Tubiello, F. N., van Velhuizen, H., 2005. Socioeconomic and climate change impacts on agriculture: an integrated assessment, 1990-2080, Phil. T. Roy. Soc. London, Series B Biological Sciences 360, 2067-2083.

Freire-González, J., 2011a. Assessing the Macroeconomic Impact of Water Supply Restrictions Through an Input-Output Analysis. Water Resour. Manage. 25(9), 2335-2347.

Freire-González, J., 2011b. Methods to empirically estimate direct and indirect rebound effect of energy-saving technological changes in households. Ecol. Modell. 223(1), 32-40.

Grafton, R.Q., Ward, M.B., 2008. Prices versus rationing: Marshallian surplus and mandatory water restrictions. The Economic Record 84, 57-65. 
Greening, A., Greene, D.L., Difiglio, C., 2000. Energy efficiency -consumption and the rebound effect- a survey. Energy Policy 28, 389-401.

Grossmann, M., Koch, H., Lienhoop, N., Vögele, S., Mutafoglu, M., Möhring, J., Dietrich, O., Kaltofen, M., 2011. Economic risks associated with low flows in the Elbe River Basin (Germany): an integrated economic-hydrologic approach to assess vulnerability to climate change. GLOWA-Elbe working paper.

Guiu, R., Pouget, L., Termes, M., 2015. Selecting an Efficient Adaptation Level to Uncertain Water Scarcity by Coupling Hydrological Modeling and Economic Valuation. Water Economics and Policy 1(3). DOI: 10.1142/S2382624X15500083.

Hensher, D., Shore, N., Train, K., 2006. Water supply security and willingness to pay to avoid drought restrictions. The Economic Record 82, 56-66.

Holden, S., Shiferaw, B., 2004. Land degradation, drought and food security in a less-favoured area in the Ethiopian highlands: a bioeconomic model with market imperfections, Agric. Econom. 30, 31-49. Horridge, M., Madden, J., Wittwer, G., 2005. The impact of the 2002-2003 drought on Australia. Journal of Policy Modeling 27, 285-308.

Howitt, R., Medellín-Azuara, J., MacEwan, D., Lund, J., Sumner, D., 2014. Economic analysis of the 2014 drought for California agriculture. prepared for California Department of Food and Agriculture by UC Davis Center for Watershed Sciences and ERA Economics.

IPCC, 2014. Climate change 2014. Assessment report.

Islam, N., 2003. What does a dry season mean to the Western Australian economy? A CGE investigation, Paper presented to the 47th Annual Conference of the Australian Agricultural and Resource Economics Society, Western Australia, 11 - 14 February, 2003.

Jenkins K., 2012. Modelling the economic and social consequences of drought under future projections of climate change. Dissertation. University of Cambridge.

Jenkins, K., 2013. Indirect economic losses of drought under future projections of climate change: a case study for Spain. Natural hazards 69(3), 1967-1986.

Jonkman, S.N., Brinkhuis-Jak, M., Kok, M., 2004. Cost benefit analysis and flood damage mitigation in the Netherlands. HERON 49(1), 95-111. 
Khazzoom, J.D., 1980. Economic implications of mandated efficiency in standards for household appliances. Energy Journal 1, 21-40.

Kirby M, Bark R., Connor J., Ejaz Qureshi M. and S. Keyworth, 2014. Sustainable irrigation: How did irrigated agriculture in Australia's Murray-Darling Basin adapt in the Millennium Drought?

Agricultural Water Management. 145, issue C, 154-162.

Kulshreshtha, S.N., Klein, K.K., 1989. Agricultural drought impact evaluation model: a systems approach, Agric. Syst. 30, 81-96.

Logar, I., van den Bergh, J., 2013. Methods to Assess Costs of Drought Damages and Policies for Drought Mitigation and Adaptation: Review and Recommendations. Water Resour. Manage. 27, $1707-1720$.

McKee, T.B., Doesken N.J., Kleist, J., 1993. The Relationship of Drought Frequency and Duration to Time Scales. In: Eighth Conference on Applied Climatology, Anaheim, California, 17-22.

McKinsey, 2009. Charting our Water Future: Economic Frameworks to Inform Decision-Making. New York: McKinsey and Company for the 2030 Water Resources Group.

Meyer, V., Becker, N., Markantonis, V., Schwarze, R., van den Bergh, J.C.J.M., Bouwer, L. M., Bubeck, P., Ciavola, P., Genovese, E., Green, C., Hallegatte, S., Kreibich, H., Lequeux, Q., Logar, I., Papyrakis, E., Pfurtscheller, C., Poussin, J., Przyluski, V., Thieken, A.H., Viavattene, C., 2013. Review article: Assessing the costs of natural hazards - state of the art and knowledge gaps. Nat. Hazards Earth Syst. Sci. 13, 1351-1373.

Michelsen, M.A., Young, R.A., 1993. Optioning agricultural water rights for urban water supplies during drought, Am. J. Agr. Econ. 75, 1010-1020.

Mysiak, J., Markandya, A., 2009. Economic costs of droughts. Xerochore WP2 Brief.

Morton, J., Barton, D., Collinson, C., Heath, B., 2005. Comparing Drought Mitigation Interventions in the Pastoral Livestock Sector, Nat. Resour. Institute report, Greenwich, NRI.

Padilla, E., 2002. Intergenerational equity and sustainability. Ecol. Econ. 41(1), 69-83.

Pagsuyoin, S.A., Santos, J.R., 2015. Modeling the Effects of Drought in Urban Economies Using Regional Input-Output Analysis. British Journal of Environment \& Climate Change 5(2), 134-146. 
Pattanayak, S. K., Kramer, R. A., 2001a. Pricing ecological services: Willingness to pay for drought mitigation from watershed protection in eastern Indonesia. Water Resour. Res. 37, 771-778.

Pattanayak, S.K., Kramer, R.A., 2001b. Worth of watersheds: a producer surplus approach for valuing drought mitigation in Eastern Indonesia, Environ. Development Econom. 6, 123-146.

Pauw, K., Thurlow, J., Bachu, M., van Seventer, D.E., 2011. The economic costs of extreme weather events: a hydrometeorological CGE analysis for Malawi. Environment and development economics 16(02), 177-198.

Penning-Rowsell, E., Johnson, C., Tunstall, S., Tapsell, S., Morris, J., Chatterton, J., Coker, A., Green, C., 2003. The benefits of flood and coastal defence: techniques and data for 2003, Enfield, Flood Hazard Research Centre.

Pérez y Pérez, L., Barreiro-Hurlé, J., 2009. Assessing the socioeconomic impacts of drought in the Ebro River Basin. Spanish J. Agric. Res. 7, 269-280.

Przyluski, V., Hallegatte, S., 2011. Indirect Costs of Natural Hazards. CONHAZ Report.

Rietveld, P., 2011. Spatial dimensions of climate change adaptation. In Proc. 53rd Annual Conference of the European Regional Science Association (ERSA), Barcelona, August 30-September 30.

Rijkswaterstaat, 2004. Droogtestudie Nederland: Samenvattend rapport fase 2a, Inhoudelijke analyse, Resultaten droogtestudie Nederland.

Rose, A., 2004. Economic principles, Issues and Research Priorities of Natura Hazard Loss Estimation. In: Modeling of spatial economic impacts of natural hazards, eds. Y. Okuyam \& S. Chang, 13-36. Greenwich: JAI Press.

Rose, A., Liao, S., 2005. Modeling regional economic resilience to disasters: a computable general equilibrium analysis of water service disruptions. Journal of Regional Science 45(1), 75-112.

Rosenberg, N.J., 1993. A methodology called "mink" for study of climate change impacts and responses on the regional scale: an introductory editorial. Clim. Change 24, 1-6.

Salami, H., Shahnooshib, N., Thomsonc, K.J., 2009. The economic impacts of drought on the economy of Iran: an integration of linear programming and macroeconometric modelling approaches. Ecol. Econ. 68(4), 1032-1039. 
Santos, J. R., Pagsuyoin, S. T., Herrera, L.C., Tan, R.R., Krista, D.Y., 2014. Analysis of drought risk management strategies using dynamic inoperability input-output modeling and event tree analysis. Environment Systems and Decisions 34(4), 492-506.

Smith, K. Ward, R., 1998. Floods: Physical processes and human impacts, John Wiley \& Sons, Chichester, UK.

Ward, F.A., Booker, J.F., Michelsen, A.M., 2006. Integrated economic, hydrologic, and institutional analysis of policy responses to mitigate drought impacts in Rio Grande Basin, J. Water Res. Pl-ASCE $132,488-502$.

Wheeler, S.A, Loch, A., Edwards., J., 2014. The role of water markets in helping irrigators adapt to water scarcity in the Murray-Darling Basin, Australia. Applied Studies in Climate Adaptation 166174.

Wittwer, G., Griffith, M., 2010. Closing the factory doors until better times: CGE modeling of drought using a theory of excess capacity, Paper presented at the GTAP 13th annual conference, Penang, Malaysia.

Woo, C., 1994. Managing water supply shortage: interruption versus pricing. J. Public Econo. 54, 145-160.

Young, R.A., Loomis, J.B., 2014. Determining the Economic Value of Water: Concepts and Methods. New York: Routledge. 


\section{Highlights:}

- Economic assessments of drought require a specific analytical framework.

- We identify two types of economic impact: 'green water' and 'blue water' droughts.

- Level and composition of hydraulic capital is a key factor in determining impacts.

- Policy-making has a key importance in shaping the economic impacts of droughts. 